\title{
HUBUNGAN KEBISINGAN DENGAN KESEHATAN PEKERJA BAGIAN PRODUKSI DI PT. CENTRALPERTIWI BAHARI FISH FEEDMILL
}

\author{
Dewi Arumsari ${ }^{1)}$
}

\begin{abstract}
Abstrak
Tingginya intensitas kebisingan di ruang produksi PT.Centralpertiwi Bahari Fish Feedmill akan memberikan dampak terhadap kesehatan pekerja, baik gangguan fisiologis maupun psikologis. Penelitian bertujuan untuk mengetahui hubungan faktor kebisingan dengan gangguan kesehatan, meliputi intensitas kebisingan, sumber kebisingan, pengendalian transmisi kebisingan, dan penggunaan APD.

Penelitian bersifat analitik dengan rancangan cross sectional, dilakukan pada bulan Juni 2017 di ruang produksi PT. Centralpertiwi Bahari Fish Feedmill. Variabel penelitian yaitu intensitas kebisingan, sumber kebisingan, pengendalian transmisi kebisingan, dan penggunaan APD dan gangguan kesehatan akibat kebisingan berupa gangguan físologis dan psikologis. Pengukuran kebisingan dengan Sound Level Meter pada 10 titik pengukuran. Wawancara dilakukan untuk mendapatkan karakteristik, serta keluhan fisologis dan psikologis pekerja.

Hasil penelitian mendapatkan bahwa tingkat kebisingan berkisar antara 79,87-92,86 dB. Sebanyak $32,5 \%$ pekerja mengalami gangguan fisiologis dan $47,5 \%$ gangguan psikologis, akibat paparan kebisingan. Namun, keseluruhan variabel tidak terdapat hubungan yang bermakna dengan gangguan kesehatan pekerja.
\end{abstract}

Kata kunci: Kebisingan, gangguan kesehatan

1)Alumni Prodi D3 Kesehatan Lingkungan Poltekkes Tanjungkarang

\section{PENDAHULUAN}

Lingkungan kerja adalah kehidupan sosial, psikologi, dan fisik dalam perusahaan yang berpengaruh terhadap pekerja dalam melaksanakan tugasnya. Kehidupan manusia tidak terlepas dari berbagai keadaan lingkungan sekitarnya, antara manusia dan lingkungan terdapat hubungan yang sangat erat. Manusia akan selalu berusaha untuk beradaptasi dengan berbagai keadaan lingkungan sekitarnya. Demikian pula ketika melakukan pekerjaan, karyawan sebagai manusia tidak dapat dipisahkan dari berbagai keadaan disekitar tempat mereka bekerja, yaitu lingkungan kerja. Selama melakukan pekerjaan, setiap pegawai akan berinteraksi dengan berbagai kondisi yang terdapat dalam lingkungan kerja.

Lingkungan kerja adalah sesuatu yang ada disekitar para pekerja dan yang mempengaruhi dirinya dalam tugas-tugas yang di bebankan. Lingkungan kerja terbagi menjadi dua jenis yaitu lingkungan kerja fisik dan lingkungan kerja non fisik. Lingkungan kerja fisik adalah semua yang mempengaruhi pegawai baik secara langsung maupun tidak langsung. Lingkungan kerja fisik di bagi menjadi 1) Lingkungan kerja yang langsung berhubungan dengan pegawai seperti pusat kerja, kursi, meja dan sebagainya; 2) Lingkungan perantara atau lingkungan umum dapat juga disebut lingkungan kerja yang mempengaruhi kondisi manusia misalnya temperatur, kelembaban, sirkulasi udara, pencahayaan, kebisingan, getaran mekanik, bau tidak sedap, warna dan lain-lain.

Lingkungan kerja non fisik adalah semua keadaan yang terjadi yang berkaitan dengan hubungan kerja, baik hubungan dengan atasan, maupun hubungan dengan sesama rekan kerja ataupun hubungan dengan bawahan.

Dalam upaya menjaga lingkungan kerja yang kondusif dan memberikan rasa nyaman terhadap para pekerja perlu diperhatikan mengenai potensi-potensi bahaya pada lingkungan kerja yang dapat menimbulkan penyakit akibat kerja. Potensi bahaya ini dapat berupa bahaya fisik, bahaya kimia, bahaya ergonomi, bahaya biologi, dan bahaya psikologi. Potensi bahaya fisik dapat berupa kebisingan, getaran, radiasi ion dan non pengion, suhu ekstrim dan pencahayaan(Nurkamri, 2012). 
Menurut Keputusan Menteri Lingkungan Hidup Nomor : KEP-48 /MENLH/11/1996, Kebisingan adalah bunyi yang tidak diinginkan dari usaha atau kegiatan dalam tingkat dan waktu tertentu yang dapat menimbulkan gangguan kesehatan manusia dan kenyamanan lingkungan. Kebisingan yang melebihi nilai ambang batas dapat menimbulkan penyakit akibat kerja berupa gangguan pendengaran yang bersifat sementara ataupun permanen. Semakin lama berada di lingkungan bising, maka semakin berisiko mengalami gangguan pendengaran. Pada tingkat kebisingan 85 $\mathrm{dB}(\mathrm{A})$, kemungkinan sebanyak $1 \%$ pekerja akan mengalami gangguan pendengaran setelah 5 tahun kerja,. Kebisingan di lingkungan kerja juga dapat berdampak lain seperti gangguan fisiologis, gangguan psikologis, serta gangguan komunikasi.

PT. Centralpertiwi Bahari (CPB) memiliki dua usaha salah satunya usaha di bidang industri pakan ikan. Tenaga kerja di PT. Centralpertiwi Bahari Fish Feedmill (CPB Fish Feedmill) berjumlah 99 orang. Waktu operasi terbagi menjadi 3 shift, shift pertama dimulai pukul 08-00 sampai dengan 16-30. Shift kedua dimulai pukul 16-00 sampai dengan pukul 00.30 dan shift ketiga dimulai pukul 00.00 sampai dengan pukul 08.30.

Dalam proses produksiknya PT. CPB Fish Feedmill menggunakan mesin-mesin yang memiliki intensitas kebisingan yang cukup tinggi. Hasil studi awal (Desember 2016), hasil pengukuran kebisingan berkisar antara 87,05$108,76 \mathrm{db}(\mathrm{A})$. Berdasarkan hal tersebut, perlu dilakukan penelitian untuk mengetahui kebisingan dengan kesehatan pekerja di bagian produksi.

\section{METODE}

Jenis penelitian yang dilakukan merupakan penelitian analitik dengan rancangan cross sectional, dilaksanakan pada bulan Juni 2017. Faktor risiko dalam penelitian ini adalah intensitas kebisingan, sumber kebisingan dan pengendalian kebisingan. Sedangkan efek adalah gangguan kesehatan yang ditimbulkan, yaitu gangguan fisiologis dan psikologis,

Populasi dalam penelitian adalah seluruh pekerja bagian produksi di PT. CPB Fish Feedmill yang berjumlah 40 orang. Tidak dilakukan pengambilan sampel.

Pengukuran kebisingan menggunakan sound level meter (SLM) di bagian intake, extruder, hammer mill, hand add, packing, boiler. Pengukuran dilakukan selama 10 menit untuk tiap dengan pembacaan setiap lima detik. Wawancara dilakukan untuk menilai keluhan dan gangguan kesehatan perkerja. Data dianalisa secara univariat dan bivariat menggunakan uji chi square.

\section{HASII}

PT. CPB Fish Feedmill terletak di jalan Ir. Sutami Km 16 Desa Sindang Sari, Kecamatan Tanjung Bintang, Kabupaten Lampung Selatan. Produksi komersial sejak November 2013 dengan kapasitas produksi sekitar 4.000 ton/bulan..

\section{Intensitas Kebisingan}

Titik pengukuran kebisingan sebanyak 10 titik dengan dua kali pengulangan. $\mathrm{Hal}$ ini dikarenakan dalam 1 shift hanya dilakukan dua kali penggilingan bahan baku sehingga mesin produksi di bagian intake dan hammermill hanya dioperasikan dua kali. Diketahui 6 titik pengukuran tidak memenuhi syarat dan 1 titik pengukuran memenuhi syarat (Tabel 2).

Tabel 2. Hasil Pengukuran Intensitas Kebisingan

\begin{tabular}{clccr}
\hline No & \multicolumn{1}{c}{ Area } & Standar dB (A) & Hasil dB (A) & Keterangan \\
\hline 1 & Hammer Mill Kasar (1) & 85 & 92,36 & Melebihi NAB \\
2 & Hammer Mill Kasar(2) & 85 & 92,86 & Melebihi NAB \\
3 & Hammer Mill Halus & 85 & 91,06 & Melebihi NAB \\
4 & Extruder (1) & 85 & 88,29 & Melebihi NAB \\
5 & Extruder (2) & 85 & 89,10 & Melebihi NAB \\
6 & Intake (1) & 85 & 92,38 & Melebihi NAB \\
7 & Intake (2) & 85 & 91,69 & Melebihi NAB \\
8 & Hand Add (mesin Hammermill) & 85 & 92,21 & Melebihi NAB \\
9 & Packing (Mesin Extruder) & 85 & 85,71 & Melebihi NAB \\
10 & Boiler (Ruang Operator) & 85 & 79,87 & Dibawah NAB \\
\hline
\end{tabular}


Berdasarkan paparan terhadap pekerja, sebagian besar pekerja $(87,5 \%)$ terpapar kebisingan melebihi Nilai ambang Batas (NAB).

Tabel 3. Paparan Kebisingan

\begin{tabular}{lcc}
\hline \multicolumn{1}{c}{ Intensitas Kebisingan } & $F$ & $\%$ \\
\hline Dibawah NAB & 5 & 12,5 \\
Melebihi NAB & 35 & 87,5 \\
\hline
\end{tabular}

\section{Karakteristik Responden}

Hasil penelitian mendapatkan bahwa sebagian besar $(57,5 \%)$ pekerja/responden telah bekerja lebih dari 3 tahun. Seluruh responden bekerja selama delapan jam/hari, dan mendapatkan istirahat selama 30 menit. Namun, lebih dari separuh responden $(57,5 \%)$ beristirahat di tempat kerja, sehingga masih mendapatkan paparan kebisingan.

Sebanyak $75,0 \%$ responden mengaku mendapatkan pemeriksaan kesehatan sebelum bekerja di perusahaan, berupa medical check-up $(75,0 \%)$. Hampir seluruh responden $(97,5 \%)$ mendapatkan pemeriksaan kesehatan rutin dari perusahaan.

Tabel 4. Karakteristik Responden

\begin{tabular}{lcc}
\hline \multicolumn{1}{c}{ Karakteristik Responden } & F & $\%$ \\
\hline Lama Bekerja & & \\
$\quad$ < 1Tahun & 2 & 5,0 \\
1 - 3 tahun & 15 & 37,5 \\
$\quad$ > Tahun & 23 & 57,5 \\
Waktu Kerja & & \\
$\quad$ jam & 40 & 100,0 \\
Waktu Istirahat & & \\
$\quad$ 30 Menit & 40 & 100,0 \\
Istirahat di Tempat Kerja & & 0,0 \\
$\quad$ Ya & 23 & 57,5 \\
$\quad$ Tidak & 17 & 42,5 \\
Pemeriksaan Sebelum Bekerja & & \\
$\quad$ Ya & 30 & 75,0 \\
$\quad$ Tidak & 10 & 25,0 \\
Jenis Pemeriksaan Kesehatan & & \\
$\quad$ Medical Check-up & 30 & 75,0 \\
$\quad$ Tidak Melakukan & 10 & 25,0 \\
Pemeriksaan Kesehatan Rutin & & \\
$\quad$ Ada & 39 & 97,5 \\
$\quad$ Tidak Ada & 1 & 2,5 \\
\hline
\end{tabular}

\section{Gangguan Kesehatan Akibat Kebisingan}

Gangguan fisiologis (Tabel 4) yang dialami responden berupa rasa mual, sakit kepala, sesak, kelelahan hingga pucat, peningkatan nadi, dan peningkatan tekanan darah. Setiap responden memiliki keluhan gangguan fisiologis yang berbeda-beda. Ada yang mengalami gangguan fisiologis berupa rasa mual saja ada pula yang lebih dari satu keluhan. Responden yang mengalami satu keluhan maupun lebih tetap terhitung satu responden.

Tabel 4. Gangguan Fisiologis

\begin{tabular}{lcc}
\hline \multicolumn{1}{c}{ Gangguan Kesehatan } & $F$ & $\%$ \\
\hline $\begin{array}{l}\text { Gangguan Fisiologis } \\
\text { Ya }\end{array}$ & 13 & 32,5 \\
$\quad$ Tidak & 27 & 67,5 \\
Mual & & \\
$\quad$ Ya & 3 & 7,5 \\
$\quad$ Tidak & 37 & 92,5 \\
Sakit Kepala & & \\
$\quad$ Ya & 8 & 20 \\
$\quad$ Tidak & 32 & 80 \\
Sesak Nafas & & \\
$\quad$ Ya & 6 & 15 \\
$\quad$ Tidak & 34 & 85 \\
Kelelahan Hingga Pucat & & \\
$\quad$ Ya & 0 & 0 \\
$\quad$ Tidak & 40 & 100 \\
Peningkatan Denyut Nadi & & \\
$\quad$ Ya & 10 & 25 \\
$\quad$ Tidak & 30 & 75 \\
Peningkatan Tekanan Darah & & \\
$\quad$ Ya & 4 & 10 \\
Tidak & 28 & 70 \\
Tidak Tahu & 8 & 20 \\
\hline
\end{tabular}

Gangguan psikologis (Tabel 5) yang dialami responden berupa kurang konsentrasi, rasa tidak nyaman, gangguan tidur, peningkatan emosi. Setiap responden memiliki keluhan gangguan psikologis yang berbeda-beda. Ada yang mengalami gangguan psikologis dengan satu keluhan saja ada pula yang lebih dari satu keluhan. Responden yang mengalami satu keluhan maupun lebih tetap terhitung satu responden.

Tabel 5. Gangguan Psikologis

\begin{tabular}{lcc}
\hline Gangguan Kesehatan & F & $\%$ \\
\hline Gangguan Psikologis & & \\
$\quad$ Ya & 19 & 47,5 \\
$\quad$ Tidak & 21 & 52,5 \\
Kurang Konsentrasi & & \\
$\quad$ Ya & 15 & 37,5 \\
$\quad$ Tidak & 25 & 62,5 \\
Tidak Nyaman & & \\
$\quad$ Ya & 10 & 25,0 \\
$\quad$ Tidak & 30 & 75,0 \\
Gangguan Tidur & & \\
$\quad$ Ya & 0 & 0,0 \\
$\quad$ Tidak & 40 & 100,0 \\
Peningkatan Emosi & & \\
$\quad$ Ya & 9 & 22,5 \\
$\quad$ Tidak & 31 & 77,5 \\
\hline
\end{tabular}




\section{Pengendalian Kebisingan}

Sebanyak $87,5 \%$ pekerja terpapar kebisingan yang bersifat statis, dan $15 \%$ mendapat paparangabungan statis dan dinamis (Tabel 6). Seluruh responden bekerja pada ruangan dengan perlindungan bising di tingkat sumber. Namun, hanya $35,0 \%$ yang mendapat perlindungan pada jalur transmisi.

Mayoritas pekerja tidak menggunakan APD $(77,5 \%)$. Hanya sebanyak $22,5 \%$ yang selalu menggunakan APD.

Tabel 6. Pengendalian Kebisingan

\begin{tabular}{lcc}
\hline \multicolumn{1}{c}{ Gangguan Kesehatan } & $\mathrm{F}$ & $\%$ \\
\hline Sumber Kebisingan & 35 & 87,5 \\
$\quad$ Statis & 6 & 15,0 \\
$\quad$ Statis dan Dinamis & & \\
Pengendalian pada sumber & 40 & 100,0 \\
$\quad$ Ya & 0 & 0,0 \\
$\quad$ Tidak & 14 & 35,0 \\
Pengendalian pada jalur transmisi & \\
$\quad$ Ya & 26 & 65,0 \\
$\quad$ Tidak & & \\
Penggunaan APD & 9 & 22,5 \\
$\quad$ Ya & 31 & 77,5 \\
$\quad$ Tidak & & \\
\hline
\end{tabular}

\section{Hubungan Variabel Penelitian dengan Gangguan Fisiologis}

Berdasarkan Tabel 7, terlihat bahwa mayoritas responden yang terpapar kebisingan dengan intensitas melebihi $\mathrm{NAB}$, tidak mengalami gangguan fisiologis $(66,7 \%)$. Hasil analisis statistik, tidak menunjukkan hubungan yang bermakna ( $\mathrm{p}$-value $>0,05$ ).

Proporsi responden terpapar sumber kebisingan statis dan dinamis lebih besar pada kelompok yang tidak mengalami gangguan fisiologis $(70,6 \%)$. Secara statistik, tidak menunjukkan hubungan yang bermakna (pvalue $>0,05$ )

Mayoritas responden yang melakukan pengendalian di tingkat sumber maupun yang melakukan pengendalian di tingkat sumber, tidak mengalami gangguan fisiologis $(65,4 \%$ dan $71,4 \%)$. Hasil analisis statistik, tidak menunjukkan hubungan yang bermakna ( $\mathrm{p}$ value $>0,05$ ).

Tidak terdapat perbedaan proporsi responden yang menggunakan APD dan tidak menggunakan APD terhadap gangguan fisiologis ( $p$-value $>0,05$ ).

Tabel 7. Hubungan Variabel Penelitian dan Gangguan Fisiologis

\begin{tabular}{|c|c|c|c|c|c|c|}
\hline \multirow{3}{*}{ Variabel } & \multicolumn{4}{|c|}{ Gangguan Fisiologis } & \multirow{3}{*}{ P Value } & \multirow{3}{*}{$\begin{array}{c}\text { OR } \\
95 \% \mathrm{CI}\end{array}$} \\
\hline & \multicolumn{2}{|c|}{ Ya } & \multicolumn{2}{|c|}{ Tidak } & & \\
\hline & $\mathrm{n}$ & $\%$ & $\mathrm{n}$ & $\%$ & & \\
\hline Intensitas Kebisingan & & & & & & \\
\hline$>\mathrm{NAB}$ & 12 & 34,3 & 23 & 65,7 & & 2,09 \\
\hline$\leq \mathrm{NAB}$ & 1 & 20,0 & 4 & 80,0 & 0,523 & $0,21-20,81$ \\
\hline Sumber Kebisingan & & & & & & \\
\hline Statis dan Dinamis & 10 & 29,4 & 24 & 70,6 & 0,320 & 0,24 \\
\hline Statis & 3 & 50,0 & 3 & 50,0 & & $0,41-13,98$ \\
\hline Pengendalian Transmisi Kebisingan & & & & & & \\
\hline Tidak & 9 & 34,6 & 17 & 65,4 & 0,697 & 1,32 \\
\hline $\mathrm{Ya}$ & 4 & 28,6 & 10 & 71,4 & & $0,32-5,44$ \\
\hline Penggunaan APD & & & & & & \\
\hline Tidak & 10 & 32,3 & 21 & 67,7 & 0,951 & $\begin{array}{c}0,95 \\
020-461\end{array}$ \\
\hline $\mathrm{Ya}$ & 3 & 33,3 & 6 & 66,7 & & $0,20-4,61$ \\
\hline
\end{tabular}

\section{Hubungan Variabel Penelitian dengan}

\section{Gangguan Psikologis}

Berdasarkan Tabel 8, terlihat bahwa mayoritas responden yang terpapar kebisingan dengan intensitas melebihi NAB, tidak mengalami gangguan psikologis $(51,4 \%)$. Hasil analisis statistik, tidak menunjukkan hubungan yang bermakna ( $\mathrm{p}$-value $>0,05$ ).

Proporsi responden terpapar sumber kebisingan statis dan dinamis lebih besar pada kelompok yang tidak mengalami gangguan psikologis $(70,6 \%)$. Secara statistik, tidak menunjukkan hubungan yang bermakna ( $\mathrm{p}$ value $>0,05)$.

Tidak terdapat perbedaan proporsi responden yang melakukan pengendalian di tingkat sumber maupun yang melakukan pengendalian di tingkat sumber $(59,3 \%$ dan $42,9 \%$ ). Hasil analisis statistik, tidak menunjukkan hubungan yang bermakna ( $\mathrm{p}$ value $>0,05$ ). 
Tidak terdapat perbedaan proporsi responden yang menggunakan APD dan tidak menggunakan APD terhadap gangguan psikologis ( $\mathrm{p}$-value $>0,05)$.

Tabel 8. Hubungan Variabel Penelitian dan Gangguan Psikologis

\begin{tabular}{|c|c|c|c|c|c|c|}
\hline \multirow{3}{*}{ Variabel } & \multicolumn{4}{|c|}{ Gangguan Psikologis } & \multirow{3}{*}{ P Value } & \multirow{3}{*}{$\begin{array}{c}\text { OR } \\
95 \% \mathrm{CI}\end{array}$} \\
\hline & \multicolumn{2}{|c|}{$\mathrm{Ya}$} & \multicolumn{2}{|c|}{ Tidak } & & \\
\hline & $\mathrm{n}$ & $\%$ & $\mathrm{n}$ & $\%$ & & \\
\hline Intensitas Kebisingan & & & & & \multirow[b]{3}{*}{0,719} & \multirow{3}{*}{$\begin{array}{c}1,42 \\
0,21-9,55\end{array}$} \\
\hline$>\mathrm{NAB}$ & 17 & 48,6 & 18 & 51,4 & & \\
\hline$\leq \mathrm{NAB}$ & 2 & 40,0 & 3 & 60,0 & & \\
\hline \multicolumn{6}{|l|}{ Sumber Kebisingan } & \multirow{3}{*}{$\begin{array}{c}2,53 \\
0,41-15,75\end{array}$} \\
\hline Statis dan Dinamis & 4 & 66,7 & 2 & 33,3 & \multirow{2}{*}{0,307} & \\
\hline Statis & 15 & 44,1 & 19 & 55,9 & & \\
\hline \multicolumn{5}{|l|}{ Pengendalian Transmisi Kebisingan } & \multirow{3}{*}{0,317} & \multirow{3}{*}{$\begin{array}{c}0,52 \\
0,14-1,91\end{array}$} \\
\hline Tidak & 11 & 40,7 & 16 & 59,3 & & \\
\hline $\mathrm{Ya}$ & 8 & 57,1 & 6 & 42,9 & & \\
\hline \multicolumn{6}{|l|}{ Penggunaan APD } & \multirow{3}{*}{$\begin{array}{c}1,17 \\
0,26-5,21\end{array}$} \\
\hline Tidak & 15 & 48,4 & 16 & 51,6 & 0,834 & \\
\hline $\mathrm{Ya}$ & 4 & 44,4 & 5 & 55,6 & & \\
\hline
\end{tabular}

\section{PEMBAHASAN}

\section{Hubungan Intensitas Kebisingan dengan Gangguan Kesehatan}

Salah satu lingkungan kerja fisik adalah kebisingan. Kebisingan dapat memberikan efek bahaya dipengaruhi olch intensitas, frekuensi, durasi dan sifat kebisingan (WHO,1995). Kebisingan di lingkungan kerja menjadi salah satu penyebab terjadinya gangguan kesehatan kepada pekerja, jika melebihi NAB yang diperbolehkan. Gangguan kesehatan ini berupa gangguan fisiologis dan psikologis.

Berdasarkan hasil uji chi square, menunjukan tidak terdapat hubungan yang bermakna antara intensitas kebisingan dengan gangguan fisiologis $(\mathrm{p}$-value $=0,523)$. Demikian pula dengan gangguan psikologis, juga tidak menunjukan hubungan yang bermakna antara intensitas kebisingan dengan gangguan psikologi ( $\mathrm{p}$-value $=0,719)$.

Menurut Kemenkes RI (2002), beberapa faktor yang mempengaruhi kebisingan antara lain intensitas bising. Intensitas kebisingan yang melebihi NAB dengan waktu pajanan 8 $\mathrm{jam} / \mathrm{hari}$ dapat menimbulkan berbagai gangguan kesehatan. Untuk NAB kebisingan yang melebihi 85 dB A waktu kerja di sesuaikan dengan intensitas kebisingan yang ada misalnya setiap penambahan $3 \mathrm{~dB}$ A maka waktu kerja menjadi setengahnya atau 4 jam (Tambunan, 2005). Namun jika waktu produksi tetap dilakukan selama 8 jam maka sebaiknya dilakukan pengendalian kebisingan pada area tersebut seperti penggunaan APD berupa ear plug dan ear muff yang dapat mengurangi tingkat kebisingan sekitar 10-25 dB A (Suma'mur, 2009). Hasil penelitian Deny (2014), mengatakan bahwa ntensitas kebisingan menjadi salah satu faktor yang mempengaruhi gangguan kesehatan, berupa gangguan fisiologis dan psikologis.

Pada penelitian ini, tidak terdapatnya hubungan antara intensitas kebisingan dengan gangguan kesehatan kemungkinan dipengaruhi oleh masa kerja yang pendek. PT CPB Fish Feedmill mulai melakukan produksi komersial pada November 2013, sehingga masa kerja terpanjang pekerja belum mencapai lima tahun. Menurut Primadona (2012), pekerja yang terpapar kebisingan berisiko mengalami penurunan pendengaran pada masa kerja liman tahun atau lebih. Gangguan pendengaran akibat bising (Noise Induced Hearing Loss) disebabkan oleh paparan bising dengan intensitas tinggi dalam jangka waktu yang cukup lama (Permaningtyas, L., dkk, 2011).

\section{Hubungan Sumber Kebisingan dengan Gangguan Kesehatan}

Sumber kebisingan di ruang produksi dapat bersifat statis (continue) dan dinamis (discontinue). Menurut WHO (1995), gangguan kesehatan akibat kebisingan dipengaruhi oleh intensitas, frekuensi, durasi dan sifat kebisingan (WHO, 1995).

Berdasarkan hasil analisis statistik (chisquare), diketahui tidak terdapat hubungan yang bermakna antara sumber kebisingan 
dengan gangguan fisiologis ( $\mathrm{p}$-value $=0,320$ ). Demikian pula dengan gangguan psikologis, juga tidak menunjukan hubungan yang bermakna antara sumber kebisingan dengan gangguan psikologi $(\mathrm{p}$-value $=0,307)$.

Sumber kebisingan untuk setiap bagian di ruang produksi berbeda. Dari data yang diperoleh di lapangan, sebanyak $87,5 \%$ responden terpapar kebisingannya bersifat statis dari mesin-mesin produksi dan sebanyak $12,5 \%$ terpapar kebisingan campuran statis dan dinamis. Kebisingan dinamis berasal dari forklift, mesin extruder, mesin hammer mill.

Pada bagian intake, kebisingan berasal dari mesin intake dan forklif. Bagian extruder, packing dan $Q C P$, kebisingan berasal dari mesin extruder. Sedangkan pekerja bagian hand add dan hammermill terpapar dari mesin hammer mill. Namun letak tempat kerja hand add berada satu lantai di atas mesin hammermill. Sedangkan pekerja bagian hammermill berada di dekat mesin.

Sumber statis dengan bising yang terus menerus lebih berbahaya daripada bising yang terputus-putus (Anggraeni Dian, 2006). Berdasarkan data yang diperoleh, sebanyak 13 orang responden mengalami gangguan fisiologis dengan keluhan mual, sakit kepala, sesak nafas, peningkatan denyut nadi dan tekanan darah. Sedangkan keluhan gangguan psikologis adalah terganggunya konsentrasi, tidak nyaman, dan peningkatan emosi.

\section{Hubungan Pengendalian Kebisingan dengan Gangguan Kesehatan}

Kebisingan dapat menimbulkan bahaya jika melebihi $\mathrm{NAB}$, sehingga perlu dilakukan pengendalian, yaitu pengendalian pada sumber, pengendalian pada jalan transmisi, dan penggunaan alat pelindung telinga.

Berdasarkan hasil analisis chi square untuk hubungan pengendalian kebisingan pada jalan transmisi dengan gangguan fisiologi, nilai $\mathrm{p}$ value $=0,972$ karena $\mathrm{p}$ value $\geq 0,05$ maka Ho diterima dan menunjukan bahwa tidak ada hubungan yang bermakna antara pengendalian kebisingan pada jalan transmisi dengan gangguan fisiologis.

Hasil penelitian mendapatkan tidak terdapat hubungan yang bermakna antara upaya pengendalian jalan transmisi kebisingan dengan gangguan fisiologis ( $\mathrm{p}$-value $=0,697)$. Demikian pula dengan gangguan psikologis, juga tidak menunjukan hubungan yang bermakna antara pengendalian kebisingan pada jalan transmisi dengan gangguan psikologi ( $\mathrm{p}$-value $=0,317$ ).

Dari data yang diperoleh di lapangan melalui kuesioner terdapat beberapa pengendalian kebisingan seperti pengendalian pada sumber, berupa penggantian komponen mesin yang rusak, perawatan mesin sesuai jadwal setiap bulannya, penggantian oli sesuai jadwal. Pengendalian pada jalan transmisi berupa ruang kedap suara pada bagian mixer, bin checker dan $Q C P$. Penggunaan APD juga merupakan salah satu pengendalian transmisi. Jenis APD untuk kebisingan berupa ear plug dan ear muff.

\section{Hubungan APD dengan Gangguan Kesehatan}

Hasil penelitian mendapatkan bahwa mayoritas pekerja $(77,5 \%)$ tidak menggunakan APD saat bekerja. Sebanyak 13 orang pekerja mengeluhkan gangguan fisiologis, dan 19 orang mengeluhkan gangguan psikologis. Hasil penelitian ini sesuai dengan Chaeran (2008) yang mengungkapkan bahwa dampak paparan kebisingan antara lain kurang pendengaran, susah tidur, dan terganggu kenyamanan kerja. Namun, hasil statistik tidak menunjukkan perbedaan proporsi responden yang menggunakan APD dan tidak menggunakan APD terhadap gangguan fisiologis (pvalue $>0,05)$ dan ganggunan psikologis ( $p$ value $>0,05$ ).

Penggunaan APD merupakan langkah terakhir dalam hirarki pengendalian kebisingan di tempat kerja. Penggunaan alat pelindung telinga dapat mengurangi tingkat kebisingan tergantung dari jenis dan noise reduction rate dari APD tersebut. Menurut Primadona, A. (2012), pengendalian kebisingan dengan APD banyak diterapkan karena relatif lebih murah dan mudah untuk dilakukan, walaupun cara pengendalian ini tidak lebih efektif dibandingkan dengan pengendalian teknis dan administratif.

Penggunaan APD berkontribusi kuat dalam pencegahan gangguan pendengaran akibat paparan kebisingan. Menurut Istantyo (2010), APD merupakan variabel yang paling berpengaruh terhadap gangguan pendengaran. Pekerja yang tidak menggunakan APD beresiko 65,297 kali untuk menderita gangguan pendengaran, dibandingkan yang menggunakan APD.

APD kebisingan terutama berupa ear plug, ear muff, dan helmet enclosure. Beberapa syarat 
yang harus dipenuhi dalam pemilihan APD adalah: 1). Kecocokan, alat pelindung telinga tidak akan memberikan perlindungan bila tidak dapat menutupi liang telinga rapat-rapat; 2). Nyaman dipakai, tenaga kerja tidak akan menggunakan APD jika tidak nyaman dipakai.

Jenis-jenis alat pelindung telinga:

1. Sumbat telinga (earplugs/insert device aural insertprotector), yaitu pelindung yang dimasukkan ke dalam liang telinga sampai menutup rapat sehingga suara tidak mencapai membran timpani. Kemampuan sumbat telinga mengurangi bising sekitar 30 dB. Pemilihan earplug jika kebisingan berkisar antara $85-200 \mathrm{~dB}$.

2. Tutup telinga (earmuff/protective caps/ circumaural protectors), yaitu APD yang menutupi seluruh telinga eksternal dan dipergunakan untuk mengurangi bising 40$50 \mathrm{~dB}$. Pemilihan earmuff jika kebisingan di atas $100 \mathrm{~dB}$.

3. Helmel enclosure, yaitu APD yang menutupi seluruh kepala dan digunakan untuk mengurangi bising $35-50 \mathrm{~dB}$. Pemilihan alat pelindung telinga :

\section{KESIMPULAN}

1. Hasil penelitian mendapatkan bahwa tingkat kebisingan berkisar antara 79,87-92,86 dB.

2. Sebanyak $32,5 \%$ pekerja mengeluhkan gangguan fisiologis akibat paparan kebisingan, antar lain mual, sakit kepala, sesak nafas, peningkatan denyut nadi dan tekanan darah.

3. Sebanyak $47,5 \%$ pekerja mengeluhkan gangguan psikologis akibat paparan kebisingan, antar lain kurang konsentrasi tidak nyaman, dan peningkatan emosi.

4. Tidak terdapat hubungan antara intensitas, sumber kebisingan, pengendalian transmisi dan penggunaan APD dengan gangguan fisiologis maupun psikologis pekerja.

\section{DAFTAR PUSTAKA}

Chaeran, M, 2008. Kajian Kebisingan Akibat Aktivitas Di Bandara (Studi Kasus Bandara Ahmad Yani Semarang). Tesis. Program Magister Ilmu Lingkungan Program Pasca Sarjana, Universitas Diponegoro, Semarang

Istantyo, D. (2011). Pengaruh Dosis Kebisingan dan Faktor Determinan Lainnya terhadap Gangguan Fungsi Pendengaran pada Pekerja Bagian
Operator PLTU Unit 1-4 PT Indonesia Power UBP Suralaya Tahun 2011. UIN Syarif Hidayatullah Jakarta, Jakarta.

Keputusan Menteri Kesehatan Republik Indonesia Nomor: 1405/MENKES/SK/XI/2002 tentang Persyaratan Kesehatan Lingkungan Kerja Perkantoran dan Industri.

Keputusan Menteri Negara Lingkungan Hidup Nomor : Kep-48/Menlh/11/1996 tentang Baku Tingkat Kebisingan.

Keputusan Menteri Tenaga Kerja Nomor: KEP51/MEN/1999 tentang Nilai Ambang Batas Faktor Fisika di Tempat Kerja

Laboratorium core. 2012. Sound Level Meter. Tersedia

http:laboratoriumcore.blogspot.co.id/2012/ 04/sound-level-meter.html [ 9 Maret 2017]

Lingkungan, Kesehatan. 2010. Pengendalian Kebisingan. Tersedia https://inspeksisanitasi.blogspot.co.id/2010 /06/pengendalian-kebisingan.html [ 7 Maret 2017]

Notoatmodjo, Soekidjo. 2012. Metode Penelitian Kesehatan. Jakarta: Rineka Cipta.

Nurkamri. 2012. Identifikasi Faktor Bahaya Dilingkungan Kerja. Tersedia http://nrkamri.blogspot.co.id/2012/10/ident ifikasi-faktor-bahaya-di-tempat.html [ 20 Januari 2017]

Permaningtyas, L., dkk. (2011). Hubungan Lama Masa Kerja dengan Kejadian NoiseInduced Hearing Loss pada Pekerja Home Industry Knalpot di Kelurahan Purbalingga LOR. Mandala of Health, Vol. 5(No. 3).

Primadona, A. (2012). Analisis Faktor Risiko yang Berhubungan dengan Penurunan Pendengaran pada Pekerja di PT. Pertamina Geothermal Energy Area Kamojang Tahun 2012. Universitas Indonesia, Depok.

Suma'mur. 2009. Higiene Perusahaan Dan Kesehatan Kerja. Jakarta.: CV Agung Seto.

Tambunan, Sihar Tigor Benjamin. 2005. Kebisingan di Tempat Kerja (Occuptional Noise). Yogyakarta: C.V Andi Offset. 138 Halaman. 